Editorial

\title{
Image, Visual Culture and \\ Pedagogical-Educational Implications ${ }^{\dagger}$
}

\author{
Simonetta Polenghi \\ President SIPED - Società Italiana di Pedagogia, 20127 Milano, Italy; simonetta.polenghi@unicatt.it \\ + Presented at the International and Interdisciplinary Conference IMMAGINI? Image and Imagination \\ between Representation, Communication, Education and Psychology, Brixen, Italy, 27-28 November 2017. \\ Published: 15 March 2018
}

Object of reflection from different disciplines, from philosophy to psychology, to aesthetics, to semiotics, to the history of art, the image, both natural and artificial and artistic, is at the center of the experiences and daily experiences of a number more and more people. In the society of visual communication, subjects prefer to see and 'read' their experiences through images, even when, unfortunately, they are not suitable for transmitting educational and training messages. This visual centrality in lifestyles and learning stimulates pedagogy to ask questions about the reflexes and the implications on growing subjects. The use of images inevitably raises questions about the processes of elaboration, the relationship between verbal texts and visual texts, the implications with the processes of signification. Therefore the need to elaborate a "grammar" of visual texts is outlined [1], to deal with the complexity of the process of reading the image, with reference to the tools offered by semiotics and visual rhetoric, we think, for example, of the significant contribution by Umberto Eco's interpretive semiotics with regard to the enhancement of the function of images in production and decoding of meanings [2]. The recent attention then by the field of studies indicated as "visual studies" [3] opens up further and interesting fronts of pedagogical research with regard to the implications between image and problems of representation, between image and subjectivity formation, in relation also to the implications that the image has on the level of corporeity, of the quantitative predominance of the visual in cultural forms contemporary, along with the possibility of tracing the gnoseological potentialities of the image [4] in parallel and beyond the linguistic modalities.

On the basis of these brief considerations, the congress stands out for its interdisciplinary approach. To you all, my best wishes for a good job and my best regards.

\section{References}

1. Cardarello, R.; Contini, A. (Eds.) Parole Immagini Metafore. Per una Didattica della Comprensione; Junior: Azzano San Paolo, Italy, 2012; p. 296, ISBN 9788884346278.

2. Eco, U. Semiotica e Filosofia del Linguaggio; Einaudi: Milano, Italy, 1984; p. XVII-318, ISBN 9788806146115.

3. Mitchell, W.J.T. Picture Theory: Essays on Verbal and Visual Representation; The University of Chicago Press: Chicago, IL, USA; London, UK, 1994; ISBN 9780226532325.

4. Pinotti, A.; Somaini, A. (Eds.) Teorie Dell'immagine. Il Dibattito Contemporaneo; Raffaello Cortina editore: Milano, Italy, 2009; p. 280, ISBN 9788860302144.

(C) 2018 by the authors. Licensee MDPI, Basel, Switzerland. This article is an open access article distributed under the terms and conditions of the Creative Commons Attribution (CC BY) license (http://creativecommons.org/licenses/by/4.0/). 